There is a strong chapter on the need for the full participation of women in moral dialogues, not least because decisions of conscience are not a matter of disembodied rationality, but of discernment, for which the contribution of women is vital.

Only in the sixth of seven chapters are specifically Christian convictions brought in, and here Kelly is mainly in dialogue with fellow Roman Catholics, and especially with the Sacred Congregation for the Defence of the Faith, whose instructions on The Ecclesial Vocation of the Theologian (1990) is subjected to a reasoned scrutiny in an appendix. The book is warm and eirenic in tone, and of more significance than its size and modesty might suggest. Its explicitly Christian sections are important for Christians of all traditions, and its general thesis is central to a plural society where there are many who too easily are sceptical of it.

RONALD PRESTON

Emeritus Professor of Social and

Pastoral Theology in the University of

Manchester.

\section{Moral theory and medical practice}

K W M Fulford, Cambridge, Cambridge University Press, 1990, 311 pages, $£ 12.50$

This is a book by an important and meticulous psychiatrist who has an extensive background in philosophy. It isn't easy to read because he struggles for exactitude and by implication almost seems convinced that it can be achieved with the words we have. He leans heavily on Sedgwick, who damaged Szasz's dismissal of mental diseases as myths on the grounds that, unlike physical diseases, there was no lesion. Both, Fulford insists, are ethically based concepts not diametrically different. At the same time, Fulford however then accuses Kendell, Roth and Boorse of failing to see that illness is an evaluative term, not a simple scientific concept. Their criticisms of Szasz fail. In other words the debate between the two sides was abortive.

Fulford believes much can develop from the acceptance that medical science has an evaluative basis. That this matters, and in practice to what, is less well demonstrated. We don't choose or change heart failure much by noticing it is evaluative. Does philosophy help renal physiology gain much from noting that waste product is evaluative? Further similarities between what are called mental diseases and physical diseases can be emphasised or minimised depending on the speaker's wishes. Highlighting similarities or differences is obviously often political. In that sense, analysis of him or her, rather than the states, is more illuminating. Human beliefs and statements portray the believer but many are inevitable; urea is a waste product.

Fulford is very aware of the need to see how words are used rather than to ask what they mean. In everyday language they are not accurate representatives for things. He prescribes the use of 'illness' to be the primary valuation of something wrong and 'disease' to be the somewhat more scientific concept. This is acceptable but perhaps necessarily an arbitrary decision achieving in some conversations greater clarity.

Perhaps he is over-optimistic that philosophical analysis will aid medical science. To some extent the past suggests otherwise. Possibly this is because the philosophers' 'obstinate search for clear meaning' impedes the more pragmatic scientists' more frequent acceptance of some error in his measurements and words, at least for the time being.

However, despite my attempts to find fault, this is an interesting, thought-provoking book which must stimulate thoughtful reflection, not least on concepts of delusion which it examines in careful detail.

\section{F A JENNER University of Sheffield}

\section{Books: information and orders}

If you wish to order or require further information regarding the titles reviewed here, please write to or telephone the BMJ Bookshop, PO Box 295, London WC1H 9JR. Tel: 071383 6244. Fax: 0713836662 . Books are supplied post free in the UK and for BFPO addresses. Overseas customers should add 15 per cent for postage and packing. Payment can be made by cheque in sterling drawn on a UK bank or by credit card (Mastercard, Visa, or American Express, stating card number, expiry date, and full name. (The price and availability are occasionally subject to revision by the publishers.) 